Nevada

Environmental

Restoration

Project

Addendum to the Corrective Action

Decision Document/Closure Report for

Corrective Action Unit 34: Area 3

Contaminated Waste Sites

Nevada Test Site, Nevada

Controlled Copy No.:

Revision No.: 0

October 2008

Approved for public release; further dissemination unlimited.

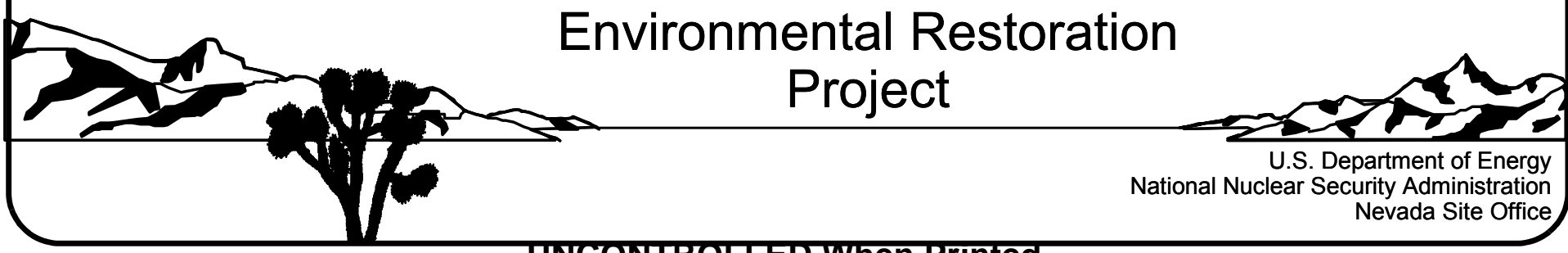


Available for public sale, in paper, from:

U.S. Department of Commerce

National Technical Information Service

5285 Port Royal Road

Springfield, VA 22161

Phone: 800.553 .6847

Fax: 703.605.6900

Email: orders@ntis.gov

Online ordering: http://www.ntis.gov/ordering.htm

Available electronically at $\underline{h t p: / / w w w . o s t i . g o v / b r i d g e ~}$

Available for a processing fee to U.S. Department of Energy and its contractors, in paper, from:

U.S. Department of Energy

Office of Scientific and Technical Information

P.O. Box 62

Oak Ridge, TN 37831-0062

Phone: 865.576 .8401

Fax: 865.576.5728

Email: reports@adonis.osti.gov

Reference herein to any specific commercial product, process, or service by trade name, trademark, manufacturer, or otherwise, does not necessarily constitute or imply its endorsement, recommendation, or favoring by the United States Government or any agency thereof or its contractors or subcontractors. 


\title{
ADDENDUM TO THE CORRECTIVE ACTION DECISION DOCUMENT/CLOSURE REPORT FOR CORRECTIVE ACTION UNIT 34: AREA 3 CONTAMINATED WASTE SITES NEVADA TEST SITE, NEVADA
}

\author{
U.S. Department of Energy \\ National Nuclear Security Administration \\ Nevada Site Office \\ Las Vegas, Nevada
}

Controlled Copy No.:

Revision No.: 0

October 2008

Approved for public release; further dissemination unlimited. 


\section{Addendum to the Corrective Action Decision Document / Closure Report for Removal of the Use Restriction}

This document constitutes an addendum to the April 2002, Corrective Action Decision Document/Closure Report for Corrective Action Unit 34: Area 3 Contaminated Waste Sites as described in the document Recommendations and Justifications for Modifications for Use Restrictions Established under the U.S. Department of Energy, National Nuclear Security Administration Nevada Site Office Federal Facility Agreement and Consent Order (UR Modification document) dated February 2008. The UR Modification document was approved by NDEP on February 26, 2008. The approval of the UR Modification document constituted approval of each of the recommended UR modifications. In conformance with the UR Modification document, this addendum consists of:

- This cover page that refers the reader to the UR Modification document for additional information

- The cover and signature pages of the UR Modification document

- The NDEP approval letter

- The corresponding section of the UR Modification document

This addendum provides the documentation justifying the cancellation of the URs for:

- CAS 03-09-06, Mud Disposal Crater

- CAS 03-09-07, Mud Pit

These URs were established as part of Federal Facility Agreement and Consent Order (FFACO) corrective actions and were based on the presence of contaminants at concentrations greater than the action levels established at the time of the initial investigation (FFACO, 1996; as amended August 2006).

Since these URs were established, practices and procedures relating to the implementation of risk-based corrective actions (RBCA) have changed. Therefore, these URs were re-evaluated against the current RBCA criteria as defined in the Industrial Sites Project Establishment of Final Action Levels (NNSA/NSO, 2006c). This re-evaluation consisted of comparing the original data (used to define the need for the URs) to risk-based final action levels (FALs) developed using the current Industrial Sites RBCA process.

The re-evaluation resulted in a recommendation to remove these URs because contamination is not present at these sites above the risk-based FALs. Requirements for inspecting and maintaining these URs will be canceled, and the postings and signage at each site will be removed. Fencing and posting may be present at these sites that are unrelated to the FFACO URs such as for radiological control purposes as required by the NV/YMP Radiological Control Manual (NNSA/NSO, 2004f). This modification will not affect or modify any non-FFACO requirements for fencing, posting, or monitoring at these sites. 
Nevada

Environmental

Restoration

Project

Recommendations and Justifications for Modifications for Use Restrictions Established under the U.S. Department of Energy, National Nuclear Security Administration Nevada Site Office

Federal Facility Agreement and Consent Order

Controlled Copy No.:

Revision No.: 0

February 2008

Approved for public release; further dissemination unlimited.

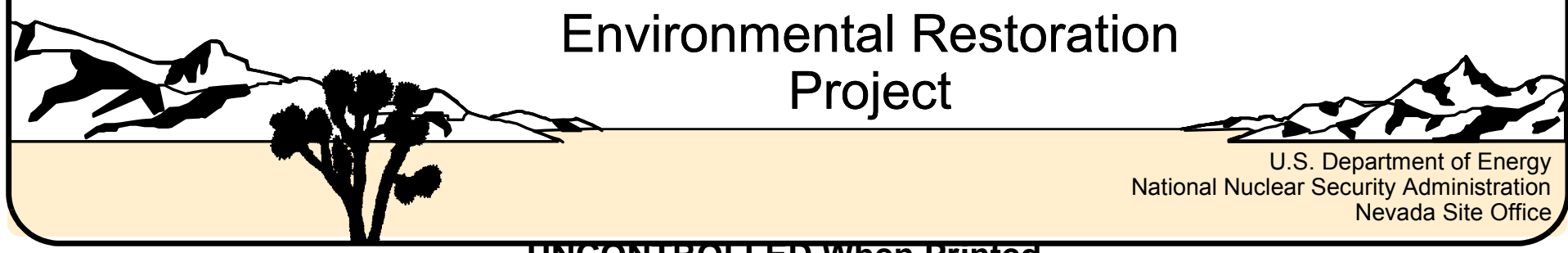


Recommendations and Justifications for Modifications for Use Restrictions Established under the U.S. Department of Energy, National Nuclear Security Administration Nevada Site Office Federal Facility Agreement and Consent Order

Approved by: /s/ Kevin J. Cabble

Date: $02 / 05 / 2008$

Kevin J. Cabble

Federal Sub-Project Director

Industrial Sites Sub-Project

Approved by:

/s/ John B. Jones

Date: $02 / 04 / 2008$

John B. Jones

Acting Federal Project Director

Environmental Restoration Project 
February 26, 2008

John B. Jones

Acting Federal Project Director

Environmental Restoration Project

National Nuclear Security Administration

Nevada Site Office

P. O. Box 98518

Las Vegas, NV 89193-8518

RE: Approval of Recommendations and Justifications for Modifications for Use Restrictions

Established under the U.S. Department of Energy, National Nuclear Security Administration, Nevada Site Office Federal Facility Agreement and Consent Order

Dear Mr. Jones:

The Nevada Division of Environmental Protection, Bureau of Federal Facilities (NDEP) staff has received and reviewed the February 2008 final report for Recommendations and Justifications for Modifications for Use Restrictions Established under the U.S. Department of Energy, National Nuclear Security Administration, Nevada Site Office. The NDEP approves the requested changes to the previously agreed upon use restrictions for those Corrective Action Sites (CASs) as described in the report.

Address any questions regarding this matter to either Ted Zaferatos at (702) 486-2850, ext. 234 , or me at (702) 486-2850, ext. 231.

Sincerely

\section{/s/ Tim Murphy}

\section{T.H. Murphy}

Chief

Bureau of Federal Facilities

$\mathrm{TZ}$

cc: $\quad$ E.F. DiSanza, WMP, NNSA/NSO

FFACO Group, PSG, NNSAINSO, Las Vegas, NV

David C. Loewer, DTRAVCXT1, M/S 645, Mercury, NV

W.R. Griffin, SNJV/DTRA, M/S 645, Mercury, NV

T.A. Thiele, NSTec, Las Vegas, NV

R.F. Boehlecke, SNJV, Las Vegas, NV

K. J. Cabble, ERP, NNSANSO, Las Vegas, NV

John Wong. Jeff MacDougall, Dennis Nicodemus, NDEP Las Vegas, NV 


\subsection{CAU 34, CAS 03-09-06 - Mud Disposal Crater}

\subsection{CAS Description}

The Mud Disposal Crater is located approximately 25 feet $(\mathrm{ft})$ north of the Area 3 Mud Plant Building, approximately 24 miles (mi) north of Mercury, Nevada, and east of Mercury Highway on Road 3-03. The Mud Disposal Crater received drilling waste and excess mud from the mud plant. The crater is approximately $314 \mathrm{ft}$ in diameter, $42 \mathrm{ft}$ deep, and was created by a 1962 underground nuclear detonation called the Chinchilla test. Later in 1962, after the test, the crater was used to mix and store mud. After 1962, the crater was used for disposal; receiving waste from Baker tanks, vacuum trucks, and the mud plant. The Mud Disposal Crater also received wastewater from the mud plant floor drains and from cleaning and flushing of mix tanks. The crater received exotic mud mixtures, including asbestos and chromate muds, used for experimentation at the mud plant between 1970 and 1972. Sometime between 1992 and 1994, the disposal of used mud and wastewater ceased (DOE/NV, 2001a).

\subsection{Current Use Restriction Description}

The future use of any land affected by this UR is restricted from any DOE or Air Force activity that may alter or modify the containment control as approved by the state and identified in the Corrective Action Unit (CAU) CR or other CAU documentation unless appropriate concurrence is obtained in advance. There are no annual monitoring or inspection requirements associated with the UR (NNSA/NV, 2002b).

\subsection{Basis for Current Use Restriction}

Samples were analyzed for TPH diesel-range organics (DRO), total VOCs, total SVOCs, total RCRA metals, polychlorinated biphenyls (PCBs), isotopic uranium (U), isotopic plutonium (Pu), strontium (Sr)-90, americium (Am)-241, and gamma spectroscopy. The analytical results for soil samples collected at the Mud Disposal Crater indicated the presence of TPH (DRO) contamination exceeding the NDEP action level of 100 milligrams per kilogram $(\mathrm{mg} / \mathrm{kg})$ at five locations. No VOCs or SVOCs were detected above PALs. Arsenic was detected above the PAL of $2.7 \mathrm{mg} / \mathrm{kg}$ in 25 of the 30 samples analyzed, but all concentrations were within the range considered representative of ambient conditions at the site. Therefore, arsenic is not considered to be a basis for this UR. The radionuclides Am-241, U-235, Pu-238, and Pu-239/240 exceeded their respective PALs. The PALs for the radionuclides were established in the Corrective Action 
Investigation Plan (CAIP) as any activity distinguishable from undisturbed background activity (DOE/NV, 2001a).

Table 3-1 contains analytical results of all COCs at CAS 03-09-06 that are the basis for the current UR. The sample matrix for all samples is soil.

Table 3-1

Sample Results for COCs at CAS 03-09-06 Used To Establish Current Use Restriction

\begin{tabular}{|c|c|c|c|c|c|c|}
\hline \multirow{2}{*}{ Sample ID } & \multirow{2}{*}{$\begin{array}{c}\text { Depth } \\
\text { (ft bgs) }\end{array}$} & TPH (DRO) & Am-241 & U-235 & Pu-238 & Pu-239/240 \\
\hline & & $\begin{array}{c}\text { PAL } \\
100 \mathrm{mg} / \mathrm{kg}\end{array}$ & $\begin{array}{c}\text { PAL } \\
0.05 \mathrm{pCi} / \mathrm{g}\end{array}$ & $\begin{array}{c}\text { PAL } \\
0.07 \mathrm{pCi} / \mathrm{g}\end{array}$ & $\begin{array}{c}\text { PAL } \\
0.05 \mathrm{pCi} / \mathrm{g}\end{array}$ & $\begin{array}{c}\text { PAL } \\
0.106 \mathrm{pCi} / \mathrm{g}\end{array}$ \\
\hline DC0101 & $1-2$ & -- & $0.94 \pm 0.17$ & -- & $\begin{array}{c}0.113 \pm \\
0.039\end{array}$ & $5.97 \pm 0.85$ \\
\hline DC0205 & $5-7$ & 180 & -- & -- & -- & -- \\
\hline DC0208 & $8-10$ & -- & $0.94 \pm 0.18$ & -- & $\begin{array}{c}0.085 \pm \\
0.034\end{array}$ & $7 \pm 1.0$ \\
\hline DC0300 & $0-0.5$ & 110 & -- & -- & -- & -- \\
\hline DC0606 & $6.5-7.5$ & -- & $0.81 \pm 0.16$ & -- & $\begin{array}{l}0.139 \pm \\
0.045\end{array}$ & $6.61 \pm 0.95$ \\
\hline DC0799 & $1-6$ & 190 & -- & -- & -- & -- \\
\hline DC0911 & $11.5-12.5$ & -- & $0.97 \pm 0.18$ & -- & $\begin{array}{c}0.078 \pm \\
0.032\end{array}$ & $7.1 \pm 1.0$ \\
\hline DC1102 & $2.5-3.5$ & $5,300(\mathrm{~J})$ & -- & -- & -- & -- \\
\hline DC1104 & $4.5-5.5$ & $8,000(\mathrm{~J})$ & -- & -- & -- & -- \\
\hline DC1211 & $11-13$ & -- & $\begin{array}{c}0.255 \pm \\
0.069\end{array}$ & -- & -- & $1.65 \pm 0.27$ \\
\hline DC0799 & $1-6$ & -- & $\begin{array}{c}0.07 \pm \\
0.025(\mathrm{~J})\end{array}$ & $\begin{array}{c}0.145 \pm \\
0.052\end{array}$ & -- & $0.38 \pm 0.086$ \\
\hline
\end{tabular}

$\mathrm{Am}=$ Americium

bgs $=$ Below ground surface

$\mathrm{DRO}=$ Diesel-range organics

$\mathrm{ft}=$ Foot

$\mathrm{ID}=$ Identification

$\mathrm{J}=$ Estimated value

$--=$ No detects above action levels $\mathrm{mg} / \mathrm{kg}=$ Milligrams per kilogram

$\mathrm{PAL}=$ Preliminary action level

$\mathrm{pCi} / \mathrm{g}=$ Picocuries per gram

$\mathrm{Pu}=$ Plutonium

$\mathrm{TPH}=$ Total petroleum hydrocarbons

$\mathrm{U}=$ Uranium 


\subsection{Basis for Use Restriction Modification}

The revised FALs for radionuclides listed in Table 3-2 were established based on the PALs presented in Section 2.2.1. The revised FALs associated with the TPH contamination were established based on the PALs of the hazardous constituents of TPH (DRO) described in Section 2.2.2. Hazardous constituents of TPH were not detected in any of the samples at concentrations greater than their respective PALs (DOE/NV, 2001a). Therefore, no contaminants are present at this site in concentrations exceeding the revised FALs. All revised FALs were established at the PAL concentrations.

Table 3-2 presents the sample results that are the basis for the current UR and demonstrate that no results exceed the revised FALs.

Table 3-2

Revised Final Action Levels for CAS 03-09-06

\begin{tabular}{|c|c|c|c|c|c|}
\hline \multirow[b]{2}{*}{ Sample ID } & \multirow{2}{*}{$\begin{array}{l}\text { Depth } \\
\text { (ft bgs) }\end{array}$} & Am-241 & U-235 & Pu-238 & Pu-239 \\
\hline & & $\begin{array}{c}\text { Revised FAL } \\
12.7 \mathrm{pCi} / \mathrm{g}\end{array}$ & $\begin{array}{c}\text { Revised FAL } \\
\text { 17.6 pCi/g }\end{array}$ & $\begin{array}{c}\text { Revised FAL } \\
13 \mathrm{pCi} / \mathrm{g}\end{array}$ & $\begin{array}{c}\text { Revised FAL } \\
12.7 \mathrm{pCi} / \mathrm{g}\end{array}$ \\
\hline DC0101 & $1-2$ & $0.94 \pm 0.17$ & -- & $0.113 \pm 0.039$ & $5.97 \pm 0.85$ \\
\hline DC0208 & $8-10$ & $0.94 \pm 0.18$ & -- & $0.085 \pm 0.034$ & $7 \pm 1.0$ \\
\hline DC0606 & $6.5-7.5$ & $0.81 \pm 0.16$ & -- & $0.139 \pm 0.045$ & $6.61 \pm 0.95$ \\
\hline DC0911 & $11.5-12.5$ & $0.97 \pm 0.18$ & -- & $0.078 \pm 0.032$ & $7.1 \pm 1.0$ \\
\hline DC1211 & $11-13$ & $0.255 \pm 0.069$ & -- & -- & $1.65 \pm 0.27$ \\
\hline DC0799 & $1-6$ & $0.07 \pm 0.025(\mathrm{~J})$ & $0.145 \pm 0.052$ & -- & $0.38 \pm 0.086$ \\
\hline
\end{tabular}

Am = Americium

ID = Identification

bgs $=$ Below ground surface

$\mathrm{pCi} / \mathrm{g}=$ Picocuries per gram

$\mathrm{FAL}=$ Final action level

$\mathrm{Pu}=$ Plutonium

$\mathrm{ft}=$ Foot

$\mathbf{U}=$ Uranium

$\mathrm{J}=$ Estimated value

-- = No detects above original action levels

\subsection{Proposed Modification}

Remove the FFACO UR and associated fencing and postings from this CAS. 


\subsection{CAU 34, CAS 03-09-07 - Mud Pit}

\subsection{CAS Description}

Corrective Action Site 03-09-07, Mud Pit, is located south of the Area 3 camp and north of the U3gd crater. The Mud Pit possibly received pre- and post-test drill waste and drill yard waste. The site consists of a mud pit approximately 315 by $245 \mathrm{ft}$ with an approximate 100-by-40-ft internal bermed area at the northeast corner of the large pit. The interior bermed area was used for disposal of excess mud from washing drilling equipment, specifically Baker and Shaker tanks. The mud pit was used for disposal from 1968 to sometime before 1974, at which time the U3ag crater (CAS 03-09-06) was used for excess mud disposal. The mud pit is currently inactive (DOE/NV, 2001a).

\subsection{Current Use Restriction Description}

The future use of any land affected by this UR is restricted from any DOE or Air Force activity that may alter or modify the containment control, as approved by the state and identified in the CAU CR or other CAU documentation, unless appropriate concurrence is obtained in advance. There are no annual monitoring or inspection requirements associated with the UR (NNSA/NV, 2002b).

\subsection{Basis for Current Use Restriction}

Samples were analyzed for TPH (DRO), total VOCs, total SVOCs, total RCRA metals, PCBs, isotopic U, isotopic Pu, Sr-90, Am-241, and gamma spectroscopy. No VOCs or SVOCs were detected above PALs. The analytical results for soil samples collected at the Mud Pit indicated the presence of TPH (DRO) contamination exceeding the NDEP action level of $100 \mathrm{mg} / \mathrm{kg}$ at 12 locations, and the presence of TPH gasoline-range organics (GRO) contamination exceeding the NDEP action level of $100 \mathrm{mg} / \mathrm{kg}$ at one location. Arsenic was detected above the PAL of $2.7 \mathrm{mg} / \mathrm{kg}$ in 44 of the 46 samples analyzed, but all concentrations were within the range considered representative of ambient conditions at the site. Therefore, arsenic is not considered to be a basis for this UR. The radionuclides Am-241, europium (Eu)-152, U-235, Pu-238, and $\mathrm{Pu}-239 / 240$ exceeded their respective PALs. The PALs for the radionuclides were established in the CAIP as any activity distinguishable from undisturbed background activity (DOE/NV, 2001a). 
Table 4-1 contains analytical results of all COCs at CAS 03-09-07 that are the basis for the current UR. The sample matrix for all samples is soil.

Table 4-1

Sample Results for COCs at CAS 03-09-07 Used To Establish Current Use Restriction (Page 1 of 2)

\begin{tabular}{|c|c|c|c|c|c|c|c|c|}
\hline \multirow[b]{2}{*}{ Sample ID } & \multirow{2}{*}{$\begin{array}{c}\text { Depth (ft } \\
\text { bgs) }\end{array}$} & $\begin{array}{l}\text { TPH } \\
\text { (DRO) }\end{array}$ & TPH (GRO) & Am-241 & Eu-152 & U-235 & Pu-238 & $\mathrm{Pu}-239 / 240$ \\
\hline & & $\begin{array}{c}\mathrm{PAL} \\
100 \mathrm{mg} / \mathrm{kg}\end{array}$ & $\begin{array}{c}\mathrm{PAL} \\
100 \mathrm{mg} / \mathrm{kg}\end{array}$ & $\begin{array}{c}\text { PAL } \\
0.05 \mathrm{pCi} / \mathrm{g}\end{array}$ & $\begin{array}{c}\text { PAL } \\
\text { Not } \\
\text { Identified }\end{array}$ & $\begin{array}{c}\text { PAL } \\
0.07 \mathrm{pCi} / \mathrm{g}\end{array}$ & $\begin{array}{c}\text { PAL } \\
0.05 \mathrm{pCi} / \mathrm{g}\end{array}$ & $\begin{array}{c}\text { PAL } \\
0.106 \mathrm{pCi} / \mathrm{g}\end{array}$ \\
\hline MP0108 & $8-10$ & -- & -- & -- & $\begin{array}{c}1.25 \pm 0.48 \\
(\mathrm{~J})\end{array}$ & -- & -- & -- \\
\hline MP0500 & $0-0.5$ & -- & -- & -- & $6.1 \pm 1.2$ & -- & -- & -- \\
\hline MP0507 & $7.5-9.5$ & 140 & -- & -- & -- & -- & -- & -- \\
\hline MP0600 & $0-1$ & -- & -- & $\begin{array}{c}0.212 \pm 0.066 \\
(\mathrm{~J})\end{array}$ & $1.97 \pm 0.48$ & $\begin{array}{l}0.079 \pm \\
0.036\end{array}$ & $\begin{array}{l}0.193 \pm \\
0.053\end{array}$ & $1.16 \pm 0.19$ \\
\hline MP0601 & $1-3$ & $48,000(\mathrm{~J})$ & 1,800 & -- & -- & -- & -- & -- \\
\hline MP0703 & $3-5$ & $11,000(\mathrm{~J})$ & -- & -- & -- & -- & -- & -- \\
\hline MP0800 & $0-0.5$ & -- & -- & $2.00 \pm 0.72$ & -- & -- & -- & $0.43 \pm 0.09$ \\
\hline MP0808 & $8-10$ & 2,300 & -- & -- & -- & -- & -- & - \\
\hline MP0900 & $0-1$ & -- & -- & $\begin{array}{c}0.125 \pm 0.032 \\
(\mathrm{~J})\end{array}$ & $\begin{array}{c}1.26 \pm 0.45 \\
(\mathrm{~J})\end{array}$ & $\begin{array}{c}0.072 \pm \\
0.038\end{array}$ & -- & $0.18 \pm 0.05$ \\
\hline MP1001 & $1-3$ & 290 & -- & -- & - & -- & - & -- \\
\hline MP1103 & $3-5$ & 930 & -- & -- & -- & -- & -- & -- \\
\hline MP1200 & $0-1$ & 210 & -- & $\begin{array}{c}0.066 \pm 0.022 \\
(\mathrm{~J})\end{array}$ & -- & -- & -- & $0.37 \pm 0.08$ \\
\hline MP1203 & $3-5$ & 130 & -- & -- & -- & -- & -- & -- \\
\hline MP1400 & $0-0.5$ & -- & -- & -- & $2.61 \pm 0.62$ & $\begin{array}{c}0.103 \pm \\
0.041\end{array}$ & -- & $0.29 \pm 0.08$ \\
\hline MP1401 & $1-3$ & 1,700 & -- & -- & $2.77 \pm 0.65$ & -- & -- & -- \\
\hline MP1499 & $0-0.5$ & -- & -- & -- & $2.55 \pm 0.64$ & -- & -- & -- \\
\hline MP1504 & $4-6$ & 5,300 & -- & -- & -- & -- & -- & -- \\
\hline MP1601 & $1-3$ & 3,300 & -- & -- & $\begin{array}{c}1.72 \pm 0.59 \\
(\mathrm{~J})\end{array}$ & -- & -- & -- \\
\hline MP1603 & $3-5$ & 200 & -- & -- & $1.95 \pm 0.58$ & -- & -- & -- \\
\hline MP1708 & $8-10$ & -- & -- & -- & $3.95 \pm 0.91$ & -- & -- & -- \\
\hline
\end{tabular}


Table 4-1

Sample Results for COCs at CAS 03-09-07

Used To Establish Current Use Restriction

(Page 2 of 2)

\begin{tabular}{|c|c|c|c|c|c|c|c|c|}
\hline \multirow[b]{2}{*}{ Sample ID } & \multirow{2}{*}{$\begin{array}{c}\text { Depth } \\
\text { (ft bgs) }\end{array}$} & $\begin{array}{c}\text { TPH } \\
\text { (DRO) }\end{array}$ & TPH (GRO) & Am-241 & Eu-152 & U-235 & Pu-238 & Pu-239 \\
\hline & & $\begin{array}{c}\text { PAL } \\
100 \mathrm{mg} / \mathrm{kg}\end{array}$ & $\begin{array}{c}\mathrm{PAL} \\
100 \mathrm{mg} / \mathrm{kg}\end{array}$ & $\begin{array}{c}\text { PAL } \\
0.05 \mathrm{pCi} / \mathrm{g}\end{array}$ & $\begin{array}{c}\text { PAL } \\
\text { Not } \\
\text { Identified }\end{array}$ & $\begin{array}{c}\text { PAL } \\
0.07 \mathrm{pCi} / \mathrm{g}\end{array}$ & $\begin{array}{c}\mathrm{PAL} \\
0.05 \mathrm{pCi} / \mathrm{g}\end{array}$ & $\begin{array}{c}\text { PAL } \\
0.106 \mathrm{pCi} / \mathrm{g}\end{array}$ \\
\hline MP1711 & $11-13$ & -- & -- & -- & $2.85 \pm 0.63$ & -- & -- & -- \\
\hline MP1907 & $7-9$ & -- & - & $0.96 \pm 0.39$ & -- & -- & -- & $0.19 \pm 0.055$ \\
\hline MP2004 & $4-6$ & -- & -- & -- & $1.75 \pm 0.52$ & -- & -- & -- \\
\hline
\end{tabular}

$\mathrm{Am}=$ Americium

bgs = Below ground surface

DRO = Diesel-range organics

$\mathrm{Eu}=$ Europium

$\mathrm{ft}=$ Foot

$\mathrm{GRO}=$ Gasoline-range organics

ID = Identification

$\mathrm{J}=$ Estimated value

-- $=$ No detects above action levels $\mathrm{mg} / \mathrm{kg}=$ Milligrams per kilogram

$\mathrm{PAL}=$ Preliminary action level

$\mathrm{pCi} / \mathrm{g}=$ Picocuries per gram

$\mathrm{Pu}=$ Plutonium

$\mathrm{TPH}=$ Total petroleum hydrocarbons

$\mathrm{U}=$ Uranium

\subsection{Basis for Use Restriction Modification}

The revised FALs for radionuclides other than Eu-152 listed in Table 4-2 were established based on the PALs presented in Section 2.2.1. The revised FAL for Eu-152 was established based on a site-specific RESRAD calculation of a $25 \mathrm{mrem} / \mathrm{yr}$ dose under an industrial scenario (see Section 2.2.2) as prescribed in Industrial Sites Project Establishment of Final Action Levels (NNSA/NSO, 2006c).

The revised FALs associated with the TPH contamination were established based on the PALs of hazardous constituents of TPH diesel and TPH gasoline described in Section 2.2.2. Hazardous constituents of TPH diesel and TPH gasoline were not detected in any of the samples at concentrations greater than their respective PALs (DOE/NV, 2001a). Therefore, no contaminants are present at this site in concentrations exceeding the revised FALs. All revised FALs other than Eu-152 were established at the PAL concentrations.

Table 4-2 presents the sample results with the revised FALs and demonstrate that none exceed the revised FALs. 
Table 4-2

Revised Final Action Levels for CAS 03-09-07

\begin{tabular}{|c|c|c|c|c|c|c|}
\hline \multirow{2}{*}{ Sample ID } & \multirow{2}{*}{$\begin{array}{l}\text { Depth } \\
\text { (ft bgs) }\end{array}$} & Am-241 & Eu-152 & U-235 & Pu-238 & Pu-239 \\
\hline & & $\begin{array}{c}\text { Revised FAL } \\
12.7 \mathrm{pCi} / \mathrm{g}\end{array}$ & $\begin{array}{c}\text { Revised FAL } \\
62.6 \mathrm{pCi} / \mathrm{g}\end{array}$ & $\begin{array}{c}\text { Revised FAL } \\
17.6 \mathrm{pCi} / \mathrm{g}\end{array}$ & $\begin{array}{c}\text { Revised FAL } \\
13 \mathrm{pCi} / \mathrm{g}\end{array}$ & $\begin{array}{c}\text { Revised FAL } \\
12.7 \mathrm{pCi} / \mathrm{g}\end{array}$ \\
\hline MP0108 & $8-10$ & -- & $1.25 \pm 0.48(\mathrm{~J})$ & -- & -- & -- \\
\hline MP0500 & $0-0.5$ & -- & $6.1 \pm 1.2$ & -- & -- & -- \\
\hline MP0600 & $0-1$ & $\begin{array}{c}0.212 \pm 0.066 \\
(\mathrm{~J})\end{array}$ & $1.97 \pm 0.48$ & $0.079 \pm 0.036$ & $0.193 \pm 0.053$ & $1.16 \pm 0.19$ \\
\hline MP0800 & $0-0.5$ & $2.00 \pm 0.72$ & -- & -- & -- & $0.43 \pm 0.09$ \\
\hline MP0900 & $0-1$ & $\begin{array}{c}0.125 \pm 0.032 \\
(\mathrm{~J})\end{array}$ & $1.26 \pm 0.45(\mathrm{~J})$ & $0.072 \pm 0.038$ & -- & $0.18 \pm 0.05$ \\
\hline MP1200 & $0-1$ & $\begin{array}{c}0.066 \pm 0.022 \\
(\mathrm{~J})\end{array}$ & -- & -- & -- & $0.37 \pm 0.08$ \\
\hline MP1400 & $0-0.5$ & -- & $2.61 \pm 0.62$ & $0.103 \pm 0.041$ & -- & $0.29 \pm 0.08$ \\
\hline MP1401 & $1-3$ & -- & $2.77 \pm 0.65$ & -- & -- & -- \\
\hline MP1499 & $0-0.5$ & -- & $2.55 \pm 0.64$ & -- & -- & -- \\
\hline MP1601 & $1-3$ & -- & $1.72 \pm 0.59(\mathrm{~J})$ & -- & -- & -- \\
\hline MP1603 & $3-5$ & -- & $1.95 \pm 0.58$ & -- & -- & -- \\
\hline MP1708 & $8-10$ & -- & $3.95 \pm 0.91$ & -- & -- & -- \\
\hline MP1711 & $11-13$ & -- & $2.85 \pm 0.63$ & -- & -- & -- \\
\hline MP1907 & $7-9$ & $0.96 \pm 0.39$ & -- & -- & -- & $0.19 \pm 0.055$ \\
\hline MP2004 & $4-6$ & -- & $1.75 \pm 0.52$ & -- & -- & -- \\
\hline
\end{tabular}

$\mathrm{Am}=$ Americium

bgs $=$ Below ground surface

$\mathrm{Eu}=$ Europium

$\mathrm{FAL}=$ Final action level

$\mathrm{ft}=$ Foot

$\mathrm{J}=$ Estimated value

-- = No detects above original action levels
ID = Identification

$\mathrm{pCi} / \mathrm{g}=$ Picocuries per gram

$\mathrm{Pu}=$ Plutonium

$\mathrm{U}=$ Uranium

\subsection{Proposed Modification}

Remove the FFACO UR and associated fencing and/or postings from this site. 


\section{References}

DOE/NV, see U.S. Department of Energy, Nevada Operations Office.

FFACO, see Federal Facility Agreement and Consent Order.

Federal Facility Agreement and Consent Order. 1996 (as amended). Agreed to by the State of Nevada; U.S. Department of Energy, Environmental Management; U.S. Department of Defense; and U.S. Department of Energy, Legacy Management.

NNSA/NSO, see U.S. Department of Energy, National Nuclear Security Administration Nevada Site Office.

NNSA/NV, see U.S. Department of Energy, National Nuclear Security Administration Nevada Operations Office.

U.S. Department of Energy, National Nuclear Security Administration Nevada Operations Office. 2001a. Corrective Action Decision Document for Corrective Action Unit 262: Area 25 Septic Systems and Underground Discharge Point, Nevada Test Site, Nevada, Rev. 1, DOE/NV--744-Rev 1. September. Las Vegas, NV

U.S. Department of Energy, National Nuclear Security Administration Nevada Operations Office. 2002b. Corrective Action Decision Document/Closure Report for Corrective Action Unit 34: Area 3 Contaminated Waste Sites, Nevada Test Site, Nevada, Rev. 0, DOE/NV--811. April. Las Vegas, NV.

U.S. Department of Energy, National Nuclear Security Administration Nevada Site Office. 2004f. NV/YMP Radiological Control Manual, DOE/NV--11718-079, Rev. 5. Prepared by Bechtel Nevada. Las Vegas, NV.

U.S. Department of Energy, National Nuclear Security Administration Nevada Site Office. 2006c. Industrial Sites Project Establishment of Final Action Levels, Rev. 0, DOE/NV--1107. Las Vegas, NV. 


\section{Library Distribution List}

\section{$\underline{\text { Copies }}$}

U.S. Department of Energy

1 (Uncontrolled, electronic copy)

National Nuclear Security Administration

Nevada Site Office

Technical Library

P.O. Box 98518, M/S 505

Las Vegas, NV 89193-8518

U.S. Department of Energy

Office of Scientific and Technical Information

1 (Uncontrolled, electronic copy)

P.O. Box 62

Oak Ridge, TN 37831-0062

Southern Nevada Public Reading Facility

2 (Uncontrolled, electronic copies)

c/o Nuclear Testing Archive

P.O. Box 98521, M/S 400

Las Vegas, NV 89193-8521

Manager, Northern Nevada FFACO

1 (Uncontrolled, electronic copy)

Public Reading Facility

c/o Nevada State Library \& Archives

100 N Stewart Street

Carson City, NV 89701-4285 